\title{
'It will enlarge the ideas of the natives': Indigenous Australians and the tour of Prince Alfred, Duke of Edinburgh
}

\author{
Jessie Mitchell
}

\begin{abstract}
Between 1867 and 1869, the Australian colonies were visited by Prince Alfred, Duke of Edinburgh, the second son of Queen Victoria and the first member of the royal family to tour Australia. This was part of Alfred's global journey onboard the HMS Galatea. Recent years have seen fascinating discussions of this tour by Cindy McCreery, who has considered the Duke's life as a transnational traveller, his intriguing public persona and the receptions he received by colonists, which brought to light local dynamics of class, gender and nationality. ${ }^{1}$ However, historians have rarely paid much attention to the Duke's encounters with Indigenous Australians. These were the first meetings Indigenous people had with British royalty on their own soil, and while they were not overtly political and yielded few material results, they still deserve consideration for their rich symbolism and for the insights they provide into imperial discourse and colonial life.
\end{abstract}

A study of these events helps to further our understanding of Indigenous relationships with the British Crown - a mixed history, the importance of which has been highlighted by scholars such as Heather Goodall, Ann Curthoys and Mark McKenna. ${ }^{2}$ By the middle of the 19th century, there had already been a petition to Queen Victoria by the people of Flinders Island (1846) and a loyal address from the Kulin nations of Victoria (1863). The Duke's receptions can be considered alongside these, but also in contrast to them, as these events of 1867-68 were mostly performative ones, staged by people who had little power to make conventional demands on the government. Nonetheless, they were keen to forge stronger links with the Crown, to increase their local standing, and to present themselves as dignified people and perhaps equal subjects. On these occasions, Alfred himself appears as a rather passive figure: the recipient of addresses and the focal point for local tensions. Nonetheless, his expressions of friendliness, paternalism and British imperialism (while conventional in themselves) could take on complex colonial meanings.

This article focuses on the main Indigenous welcomes, held in South Australia, Victoria, Queensland and New South Wales. Two Indigenous people, Truganini

1 McCreery 2008; McCreery 2007; McCreery 2004.

2 For instance, Curthoys 2008: 94, 100-102; Goodall 1996: 76-77; McKenna 2004. 
and William Lanne, were present at the Duke's reception in Hobart in January 1868 , but they do not appear to have met him, and their odd status, marginalised and fetishised as the 'last of their race', has already been noted by McCreery. ${ }^{3}$ Nor have I found any mention of the Duke meeting Indigenous people in Western Australia during his 1869 visit, although plans for a corroboree had been made for his first (cancelled) trip in $1867 .{ }^{4}$ Royal receptions varied greatly between districts. They drew attention, for example, to issues like missionary evangelising in South Australia, the rise of the protection board in Victoria and frontier violence in Queensland, and they serve as a reminder of the diversity of colonial experiences and agendas. At the same time, royal welcomes were affected by wider ideas about empire, monarchy, race and civilisation, and they were publicised and interpreted through colonial and imperial books, journals and newspapers, as part of the obsessive attention paid to Alfred's travels. As imperial and transnational scholars have observed, the British world of the 19th century saw the movement of ideas, materials, stories and people across boundaries, reshaping and being reshaped by one another. The Duke's Australian travels were marked by a complex interplay between personal, local and British elements. ${ }^{5}$

These occasions also offer new insights into histories of colonial performance, as Indigenous people, missionaries, colonists and the royal party themselves were put on display. These receptions were exciting occasions which allowed for unusual behaviour and unexpected encounters, while at the same time people were expected to perform versions of their 'typical' selves. The result was a mixed process whereby hierarchies of British and colonial life were both reinforced and challenged. Michael Parsons, Jane Lydon, and Anna Haebich and Jodie Taylor have noted that performances, however exploitative or unsatisfactory, were one of the most common and iconic ways Indigenous people and colonists related to each other in public life. ${ }^{6}$ A royal visit was an especially potent symbolic occasion. In recent years, international scholars such as Ian Radforth and Jim Miller have examined approaches to the Crown by First Nations people, who negotiated paternalism and exotic performance to proclaim their British loyalty and cultural specificity, and to call for redress of grievances. ${ }^{7}$ Australian studies serve as both an addition and a contrast to this. The political and economic status of Indigenous Australians was much lower, and their involvement in the welcomes of 1867-68 consequently weaker, but they did try to make statements of their own. In considering their efforts, our attention is drawn to both the significance and the limitations of public symbolism, for people with few avenues of protest and little access to other forms of power.

3 McCreery 2007: 37; Mercury, 10 January 1868: 2.

4 See Perth Gazette and West Australian Times, 23 August 1867: 3, 27 September 1867: 3, 11 October 1867: 2.

5 Curthoys 2002: 146-147; Deacon et al 2009: xiv; Lambert and Lester 2006: 1-31; Tyrell 2001: 356.

6 Haebich and Taylor 2007: 63; Lydon 2005: 26-27; Parsons 2002: 46-69.

7 Miller 2004; Radforth 2003. 


\section{South Australia}

The first Indigenous welcome for the Duke was held in November 1867 in South Australia, when the royal party stopped at Woomeran, Loveday Bay. This was near the Point MacLeay mission, set up by the Congregationalist clergyman and ethnologist George Taplin in 1859, amongst the Ngarrindjeri peoples of the Lower Murray lakes. Some 500 Ngarrindjeri travelled within and between their ancestral districts to greet the Duke. This event had an internal importance for these communities, reuniting kin who had been living apart, and providing an occasion for negotiations, vaccinations, fights and church services to be held. At the same time, they were keenly aware of the significance of a royal visit. Many dressed up, while the men practised marching 'so as to appear in an orderly manner before the Duke'. However, problems soon arose. The local protector, EB Scott, had encouraged them to attend so that he could show them off, but he also caused offence by trying to control their movements. His incorrect instructions caused some people to arrive late, and he urged them to remain in the scrub away from the royal landing place, even forbidding them to fetch water. In the end, Taplin, irritated by Scott's behaviour, led them to the lake anyway, and the people declared 'Minister is our master, we must do what he tells us'. ${ }^{8}$ For the Duke's arrival, the Ngarrindjeri crowd held up a Union Jack, a banner stating 'Point Macleay' and 'Welcome to our country', and a red, white and blue flag reading 'Goolwa blackfellow big one glad see im Queen picaninny'. ${ }^{9}$ I have not discovered who wrote the slogan - it suggests a settler's wish to portray Indigenous people as foreign and comical - but the symbols combined to send a complex message of imperial loyalty, Indigenous specificity and attachment to the countryside. Assuming settlers had some involvement, it is also indicative of their wish to utilise Indigenous imagery when portraying their own identity.

Thus, even before the Duke arrived, his visit brought to the surface powerful local elements: the enduring connections between Ngarrindjeri families, the mingled paternalism and protection supplied by mission life, the tensions between missionaries and settler authorities, and the struggles for control over the landscape and the movements of people within it. The contrast between the two forms of travel which brought the Duke and the Ngarrindjeri to this place also draws attention to an irony noted by Ann Curthoys: that Aboriginal Australians have commonly been labelled 'nomadic' when trying to remain on their lands, by colonists whose own lives were shaped by arrival, exploration and distance from home. ${ }^{10}$

Upon the Duke's arrival, a welcoming address, signed by 24 people, was read out by an adolescent boy called George Pantuni, who was flanked by young people in European dress and older people in traditional cloaks. ${ }^{11}$ His speech was a break with Indigenous tradition, where senior diplomacy was the province of the

8 Taplin, Diaries: 1-11 November 1867, PRG 186-1/12, vol 6, 4/5 fiche, Edith Gertrude Beaumont Papers, State Library of South Australia [hereafter SLSA]; Taplin 1879[1873]: 111-112.

9 Milner and Brierly 1869: 177.

10 Curthoys 1999: 14.

11 Jenkin 1979: 151. 
elders, although their presence and Pantuni's facility with English might suggest a certain willingness to let him speak. Pantuni welcomed the Duke and wished him a safe journey. He explained that the men were going to dance for him as they used to before the white people came, but that he must not misunderstand and think that they were 'wild blacks'. In fact, these people had had a Christian education and gathered every Sunday 'to pray to the same God and hear of the same Jesus as your Royal Highness does.' He went on:

Some have given up native customs and become real Christians, and many others are learning the way. Many of us got an honest living by working like white people. We have often been told about the Queen your mother, and we hope and pray that God will always bless her, and may His blessing rest upon her children, especially yourself, and may He take care of you till you see your mother's face in England again. ${ }^{12}$

Pantuni's speech asserted his people's dignity, civilisation and British subjecthood, along with a complex disavowal and maintenance of Ngarrindjeri traditions. ${ }^{13}$ His speech was shaped by mission life, which provided the only setting where large numbers of Indigenous people could communicate with the royal party in any sustained way, however conventional or diluted. This scene was also reminiscent of a wider tradition of native peoples in other parts of Australia - and throughout the empire - appealing to the Crown for protection and support. The language of paternalism was significant here, and it carried several layers of meaning. Henry Reynolds, for instance, describing appeals to the Crown by Indigenous Tasmanians, notes how the discourse of paternalism could be absorbed, to some degree, into their own language of kinship. ${ }^{14}$ In the case of the Ngarrindjeri, though, I would add that the references to Queen Victoria and her children fitted in with the queen's public image as wife, mother and symbol of domestic love. ${ }^{15}$ Here, Indigenous people can also be seen as drawing on more mainstream British traditions.

Taplin reported that Pantuni spoke well. The missionary was hopeful that the Duke's visit would further his own campaigns for Christian civilisation: 'It will enlarge the ideas of the natives, and give them notions of rank and honour and dignity, which it was difficult to make them understand before. ${ }^{\prime 16}$ However, if this was a statement of British hierarchy, it was also an acknowledgement that local authority was contested. Taplin had an uneasy history with his neighbours, who had accused him of ambition and greed, prompting an investigation by the Legislative Council in $1860 .{ }^{17}$ While the committee had exonerated Taplin of wrongdoing, he was presumably concerned for his image during the royal visit. When Scott neglected to introduce the speakers properly, an angry Taplin felt

12 Argus, 19 November 1867: 5; Anon 1867: 54; Register, 14 November 1867: 3.

13 Taplin, Diaries: 11 November 1867, PRG 186-1/12, vol 6, 4/5 fiche, SLSA.

14 Reynolds 2004[1995]: 12, 25.

15 Tyrell 2000: 120.

16 Taplin 1879[1873]: 112-113.

17 Jenkin 1979: 85-95. 
obliged to send Pantuni forward alone, 'lest it be said I merely got up the address to obtain personal notice to myself.' ${ }^{18}$ If the visit drew attention to missionary work, it also highlighted Taplin's limitations.

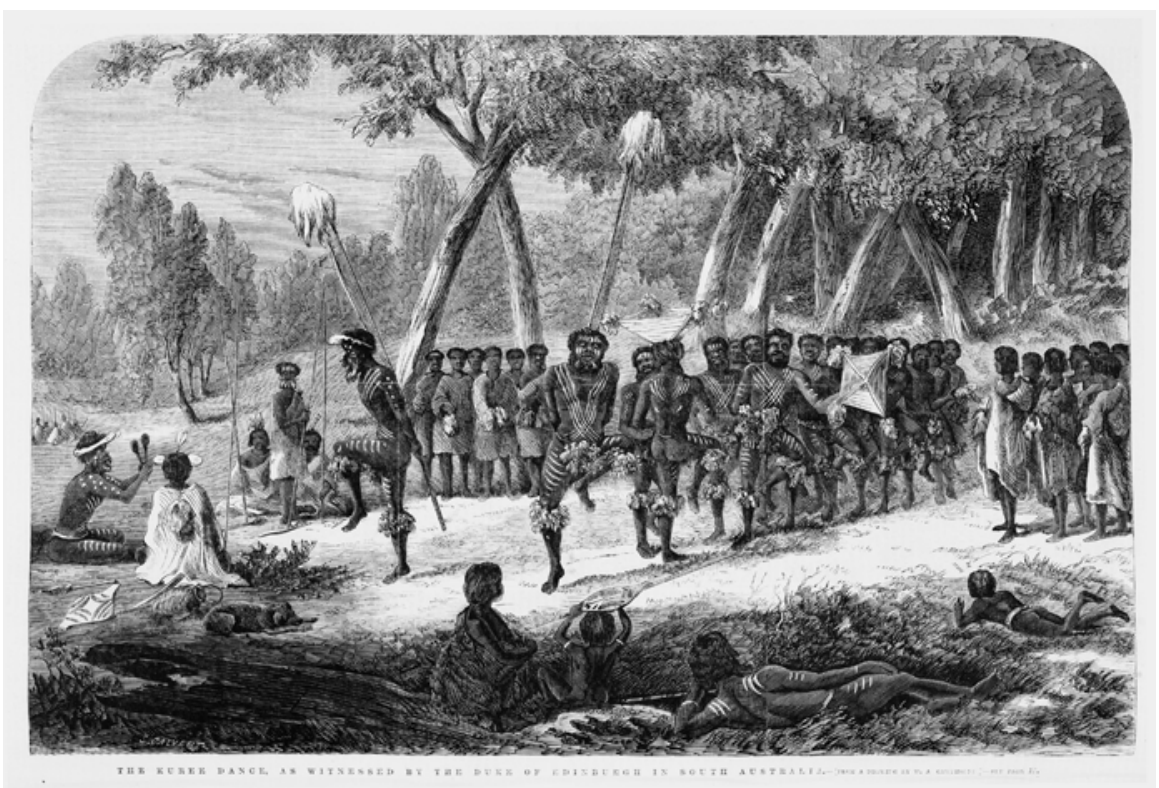

Samuel Calvert "The Kuree Dance, as witnessed by the Duke of Edinburgh in South Australia. Illustrated Australian News 26 November 1867.

(Reproduction rights owned by the State Library of Victoria, Accession no. IAN 26/11/67/8. Image no. $\mathrm{mp}$ 001227)

Perhaps the most prominent part of the Duke's reception were the songs and dances held to welcome him. At the lakeside, mingled elements of protocol, kinship, material wealth and colonial power became clear. Most Ngarrindjeri people refused to dance until their relatives had all arrived, and an odd situation of enticement and coercion followed, as impatient colonists roamed the camp offering money to people, while Scott tried to bully them into performing. Taplin wrote crossly 'They say he threatened them \& was very angry to make them dance \& sing.' Later, however, a larger group gathered, and the men painted themselves in intricate patterns before the corroboree. Witnesses noted that they took great care with their display, but would not explain its meaning to the colonists and royal party watching. ${ }^{19}$

In this respect, they were continuing a long colonial tradition. Parsons, and Haebich and Taylor have noted that corroborees were often staged for colonial audiences during the 19th century. They could be a way for impoverished people to turn their cultural knowledge into material profit, but they were also used to conciliate colonists and governors, and could be held on queen's birthdays or

18 Taplin, Diaries: 11 November 1867, PRG 186-1/12, vol 6, 4/5 fiche, SLSA.

19 Taplin, Diaries: 12-13 November 1867, PRG 186-1/12, vol 6, 4/5 fiche, SLSA; Woods 1868: 85-87. 
to welcome important guests. Parsons adds that public corroborees may have also enabled the maintenance of some restricted ritual knowledge, as their significance was rarely explained to white observers. ${ }^{20}$ Jane Lydon takes this further, observing that visual and embodied performances were crucial to how Indigenous societies experienced human relations and ties to land. At their best, performances were public assertions of rights to knowledge and country, and of reciprocal connections between visitors and hosts. ${ }^{21}$

Responses from the Duke's party were mixed. One account stated that the viewers saw the dance as strange and absurd, but also admired its precision and skill. ${ }^{22}$ Parsons has noted that many white audiences did not want to understand corroborees, but preferred to assume that they were generically mysterious, their supposed universal strangeness helping (paradoxically) to create a sense of the Australian landscape as unified and familiar. ${ }^{23}$ This helps to explain the enthusiasm with which colonists across different districts called for 'the Aborigines' to be gathered and made to dance for the royal party. This was part of a wider exhibition of colonial unity and stability.

The Duke's own response was layered. He thanked the 'Men of the Lake Tribe' for their welcome and expressed pleasure at meeting them. He added that he hoped their children would become good Christians and emulate colonial civilisation. Perhaps necessarily, he combined interest in their performance with support for missionary evangelising, remarking:

The unusual sight of some of your national customs, which owing to civilization and christianity [sic] are rapidly falling to disuse, tends to assure me of the progress you are making to a good end, and of the success which is evidently attending the kind endeavours of teachers and instructors. ${ }^{24}$

Ngarrindjeri dances and songs were welcome here - and indeed aggressively demanded - yet in the Duke's address they were associated with a way of life assumed to be vanishing for the best. Connecting with the familial language of Pantuni's speech, the Duke promised to tell the queen of 'the touching manner in which you ask the blessing of the God you have learned to worship, in common with us, to fall on her and on her family. ${ }^{25}$ Following the dance, he sent for his own musician to play the bagpipes, 'much to the astonishment and gratitude of the natives, who had probably never heard such music before. ${ }^{26}$ The piper's performance may have been intended as another sign of empire, but its strangeness in this landscape was made apparent by the Ngarrindjeri response,

20 Haebich and Taylor 2007: 63-84; Parsons 2002: 14-26; Parsons 1997: 46-69.

21 Lydon 2005: 26-27.

22 Woods 1868: 87.

23 Parsons 2002: 18.

24 Anon 1867: 54-55.

25 Anon 1867: 54-55.

26 Milner and Brierly 1869: 179. 
and the reciprocal nature of the musical moment - mutual performances being important to Indigenous welcomes ${ }^{27}$ - may have allowed the participants, albeit briefly, to step outside of any simple model of domination.

However, if this was an unusual public moment, it also brought to light conflicts which were all too familiar. After the men had performed, some women agreed to sing and dance too, but were disrupted when a white man in the crowd asked them to take off their clothes. The women were offended, and demanded 'What for blackwoman do that, when whitewomen no do it?' ${ }^{28}$ This request was presumably seen as a slur upon the women's dignity and Christianity it raised questions, too, about the respectability of the royal party watching. It also had local resonance. According to the South Australian Register, the man in question was the Hon John Baker, a successful pastoralist and conservative politician whose run was used to host the Duke's visit, and who had a hostile history with the missionary Taplin, as they vied for control over the surrounding land. ${ }^{29}$ Sexual, racial and geographical tensions could be nastily personal, but they also connected with wider colonial and imperial worlds as they were reported in the press. The back-and-forth nature of controversy and story-telling became alarmingly clear when the argument with the Ngarrindjeri women was described in the Register, and John Baker's son stormed into the editor's office and assaulted him - an event which was then reported in other colonial papers. ${ }^{30}$

If performance was one way of establishing a relationship with the Crown, the use of the countryside was another. Here, conflicts resurfaced, as Ngarrindjeri men wanted to show the Duke how they hunted kangaroo, but found that Baker shut them out of the festivities. They complained furiously to Taplin 'John Baker been steal our prince. ${ }^{\prime 31}$ As it turned out, the Duke's hunting trip was an unsatisfactory experience for him too; the royal party had hoped to travel privately and were vexed when large crowds of settlers gathered to watch. ${ }^{32}$ McCreery has noted Alfred's dislike of pomp and his preference for informal male gatherings; this was an escape from public life but also part of Alfred's public image. ${ }^{33}$ A different dynamic developed, though, during his hunting expedition at Yorke's Peninsula, 'with blackfellows and dogs'. They were guided, one source said, by 'an eccentric old native'; presumably, Indigenous men were exercising a certain quiet control over the party's movements. Here, native guides were welcomed for their expertise, but they occupied a curious position: neither servants, equal participants, nor members of the public. Still, a brief closeness was shared, as the party shot kangaroos and possums together and slept overnight in a woolshed. These Indigenous men were also amused by the astonished delight of the English guests when they first glimpsed kangaroos. This

27 Lydon 2005: 27.

28 Argus, 19 November 1867: 5; Register, 14 November 1867: 3.

29 Anon 1969: 75-76; Account reproduced in the Mercury (Hobart), 25 November 1867: 4; Perth Gazette and West Australian Times, 20 December 1867: 3; Jenkin 1979: 85-95.

30 See Mercury (Hobart), 25 November 1867: 4.

31 Taplin, Diaries: 13 November 1867, PRG 186-1/12, vol 6, 4 /5 fiche, SLSA.

32 Woods 1868: 85, 88.

33 McCreery 2008: 57-58, 69; McCreery 2007: 31. 
moment drew attention to the royal party's particular status: as imperial visitors assuming their right to the landscape, but also as foreigners new enough to be fascinated by this alien land and aware of their own displacement within it. ${ }^{34}$

A different combination of power and bewilderment took place during the Duke's last recorded Indigenous encounter in South Australia. When travelling past Wellington and Mount Barker along the Murray River, the royal party came across a platform: a burial site holding the preserved bodies of five people. They paused in the rain to behold it, and in a memoir by Oswald W Brierly, captain of the Galatea, this was portrayed as symbolic. The scene, he said, 'had a dreary, sad look, which was quite in keeping with the idea that the race was fast passing away' ${ }^{35}$ On this occasion, Indigenous people were not there to control the use of their lands and prevent the strangers' access to sensitive sites. Furthermore, even the relatively friendly and active encounters they had had with the royal travellers could not stop the myth of their supposedly natural extinction being promulgated in yet another public account.

\section{Victoria}

Victorian residents had also hoped to stage elaborate corroborees for Alfred's arrival. ${ }^{36}$ Andrew Porteous, for example, a pastoralist at Mt Emu Creek, received a request from the organisers of the royal reception to send as many Aborigines as possible to Buninyong to dance for the Duke. ${ }^{37}$ Such plans show the power that squatters in the western districts were assumed to wield over Indigenous people. However, the Victorian events also demonstrated another notable development in this region: the exceptional powers being assumed by the Central Board Appointed to Watch over the Interests of the Aborigines. In the above case, Porteous told the Board that he was concerned about the proposed corroborees, reminding them that some men invited to dance in Ballarat the previous year had become so ill and drunk that two of them died. In response, the Board issued a circular banning Indigenous people from townships during the royal visit. ${ }^{38}$ The increased travel of colonists and British visitors around Victoria as part of the Duke's tour was to be accompanied by an inverse process of tighter restrictions on Indigenous movement.

The Board's concerns about drunkenness and exploitation may have been legitimate, but it is tempting to wonder if they were also hoping to avoid political awkwardness. For, if Indigenous Victorians had suffered disproportionately from government control and loss of land, they had also begun to develop unusually visible activism. 1867 had already seen successful protests by

34 Woods 1868: 96-97.

35 Milner and Brierly 1869: 188-189.

36 Argus, 23 October 1867: 5, also 16 October 1867: 5, 19 October 1867: 5, 29 November 1867: 6, 3 December 1867: 7.

37 Clark 2008: 97, 101-107; Victoria: Sixth Report of the Central Board, 1869: 34.

38 Argus, 28 October 1867: 5; Clark 2008: 97, 101-107; Victoria: Sixth Report of the Central Board, 1869: 34. 
people around Warrnambool to prevent the Board from closing their station at Framlingham. ${ }^{39}$ Moreover, the Kulin peoples, who were forming a strong community on Coranderrk station near Healesville, had already sent gifts and declarations of allegiance to Queen Victoria and her family, and the popular mythology surrounding Coranderrk portrayed it as a gift from the queen on their traditional lands. ${ }^{40}$ Indeed, at the 1863 governor's levee where the Woiwurrung and Daungwurrung spokesmen presented their addresses to the Crown, they included a present for Prince Alfred and were pleased to hear that he might visit them. ${ }^{41}$ The relative security and progress of Coranderrk had been noticed by other communities keen to acquire their own reserves. ${ }^{42}$ However, the chance to raise these issues (or any others) at a royal reception was denied.

The Duke did meet some Indigenous men in Victoria, though, and these meetings could involve performative elements and links to wider networks. One man described only as Jim who worked for Mr Brodie of Bulla Bulla - presented an address for the Duke in Sunbury, the country of the Marin Balug clan of the Woiwurrung people. The address, which seemed to have been penned by a European, assured the Duke of the loyalty of the Aboriginal race to the British Crown and hoped that he would enjoy his visit and return safely to 'our great mother, to whom, through you, we proffer our allegiance and homage' ${ }^{43}$ The sentiments were conventional, but given the history of Woiwurrung activism, the man's wish for a connection with the Crown may well have been serious.

Nonetheless, such encounters were brief and their records fragmented. They did not allow for the deeper dynamics of community and country implicit in the South Australian gathering; rather, the press tended to load onto a handful of Indigenous men the task of symbolically representing their whole race - and, at times, standing in for its supposed failings and downfall. This became apparent when one man tried unsuccessfully to present himself to the Duke in Geelong. This was Dan-dan-nook or King Jerry, apparently one of the last survivors of the Barrabool clan of the Wathawurrung. His appearance at the public celebrations was dignified, and it connected him with Geelong society and a wider literary world. He was wearing a new suit, with a rifleman's badge and a medal from the athletics club showing that he had once been the fastest runner in the township. The press described him 'taking his seat on the steps of the dais before the Prince arrived, and looking calmly upon the brilliant scene, as if he was the monarch of all he surveyed.' 44 (The bestowing of king-names upon Indigenous men was a mocking gesture by colonists, and here the press referred frequently to the contrast between these two 'royal' figures.) He planned to present the Duke with a book on Aboriginal languages by Daniel Bunce, an English botanist,

39 Critchett 1992[1980]: 14.

40 Barwick 1998: 66; Broome 2005: 124-125, 129; Victoria: Fourth Report of the Central Board, 1864: 20.

41 Argus, 26 May 1863: 5, 27 May 1863: 5; Victoria: Third Report of the Central Board, 1863: 11.

42 Clark 2008: 101-107.

43 Argus, 14 February 1868: 5. For more about Woiwurrung language and clans, see Clark 1990: 383-384.

44 Geelong Advertiser, 3 December 1867: 2; Geelong Register, 2 December 1867: 2. 
traveller and journalist who had settled in western Victoria. ${ }^{45}$ This work described Indigenous languages and cultural practices, and portrayed them as an intelligent, ill-used race. For its time, it was a sympathetic publication, but I have not discovered whose idea it was for Dan-dan-nook to present it, or how much he knew about its contents. ${ }^{46}$ This edition contained a picture of him and an inscription dedicating the book to the Duke as a specimen of Aboriginal languages and describing Dan-dan-nook as the remaining representative of his tribe. ${ }^{47}$ His status as the 'last' Barrabool man allowed him entry into this imperial milieu but it also isolated him, and ultimately he missed the Duke's arrival. The mayor of Geelong presented the book instead, out of kindness or perhaps the wish to make a memorable local present. ${ }^{48}$ Thus, Dan-dan-nook, who may have hoped to be greeted as an equal subject and/ or an original owner of the land, was reduced instead to a portrait, both immortalised and dismissed.

Another man in the western district was more successful, when the Duke spent a day at Hopkins Hill, Mr Moffat's station. Here, tensions developed again between the Duke's wish for privacy and the demands for contact by Moffat's white neighbours. ${ }^{49}$ However, Alfred made an exception for a Dhauwurdwurrung man called Jim Cain. Cain had taken his English name from a whaler, worked for Richard Rutledge (one of the early pastoralists of Port Phillip) and visited Sydney several times. Thus, Cain was a traveller himself, with some wider colonial links, yet also determined, apparently, to remain around his homeland. The press noted that Cain was delighted by the Duke's wish for an introduction. ${ }^{50}$ However, if this meeting was exceptional, it also brought to light long-standing racial tensions. Ian D Clark has traced Dhauwurdwurrung resistance to pastoralism during the 1840s, which was broken by the Native Police, and by the middle of the century the remaining Dhauwurdwurrung survived through hunting, charity and station work. ${ }^{51}$ When the Warrnambool Examiner described the handshake between Cain and the Duke, a history of dependence, resentment and coexistence lay behind this. The writer complained that Cain would not stop boasting about the royal compliment:

The circumstance has made him as proud as Lucifer, and from the time of the hand-shaking, Jim has evinced a great disinclination to lower his dignity by performing any kind of work. Having heard that it was not the custom of His Royal Highness to shake hands with anyone, and that only one of Mr Moffat's guests (Mr Richmond Henty) had been so honoured, Jim's conceit knew no bounds. 'Mine big one fellow now', said Jim; 'Duke shake hands along o' me; lick all you _ white fellows; Duke

45 Holden 1966: 176-177.

46 Bunce 1856: v-x, 1-59.

47 Argus, 2 December 1867: 5, 3 December 1867: 5; Knight 1868: 117-118.

48 Geelong Advertiser, 3 December 1867: 3; Knight 1868: 117-118. For more on Dan-dan-ook, see Clark 1990: 304-305, 330.

49 Hamilton Spectator, 27 November 1867: 2, 4 December 1867: 2, 11 December 1867: 2.

50 Clark 1990: 30, 49, 51; Rutledge 1967: 411-412; Warrnambool Examiner, 13 December 1867: 3.

51 Clark 1990: 33-34, 48. 
no shake hands with Bill Rutledge even, only 'long o' me; mine fust-rate chap now', etc etc. I believe that the darky intends to call himself Duke Alfred for the future. ${ }^{52}$

Cain was mocked here, but given the Duke's avoidance of local colonists, Cain's own ridicule of the settlers around him also carried a sting. The royal encounter was a fleeting one, and Cain probably appeared as a curiosity to the Duke's party. However, the novelty went both ways, and if Cain showed conventional loyalty to the Crown, he was also able to disrupt (albeit momentarily) the local hierarchies of settler society.

\section{Queensland}

If immediate frontier violence had mostly finished in Victoria by 1868 , this was not the case in the north. Widespread and bloody dispossession accompanied the spread of colonialism in Queensland, and this fact was both obscured and signified in the welcome for the royal party in Brisbane. Here, alongside the other military units, the Duke was greeted and escorted by the Native Mounted Police (NMP)..$^{53}$ Behind their neat parade lay a frightening history of two decades of paramilitary support for the pastoralist sector. ${ }^{54}$ Early in 1868, at the same time as the Duke's reception was being planned, heated debates were taking place about this armed body. Several politicians called for the NMP to be abolished or reformed, alleging that atrocities and massacres were being committed, as part of a policy of 'extermination'. Other speakers disagreed, claiming that protecting settlers should be the first priority, or worrying that getting rid of the police force would only lead to greater unofficial violence towards Aborigines. Some commentators sneeringly described Indigenous people as animals who must be destroyed, and there were angry debates about whether they were really British subjects at all. Police officers were urged (apparently fruitlessly) to operate in a more cautious, accountable way, but ultimately the opponents of the NMP did not have the parliamentary numbers to force real change. ${ }^{55}$ The practice of sending native troops to discipline or terrorise people in neighbouring regions was used in various British realms, and as Julie Evans has argued, discrimination and cruelty towards colonised people can be seen as producing the very rule of law that was being broken. ${ }^{56}$ The presence of the NMP at the Duke's welcome could be taken as a statement of their ongoing use and connection to the empire.

However, the NMP were not the only Indigenous men present. Before the royal ship docked, another group lined up along the gangway, to the surprise of most of the crowd: 'a band of natives, in war costume, with their bodies painted with various coloured clays, and their hair ornamented with feathers'. There were

52 Warrnambool Examiner, 13 December 1867: 3.

53 Queensland Daily Guardian, 25 February 1868: 2; Queenslander, 29 February 1868: 2.

54 Evans 2007: 71-75; Reynolds 2001: 105-118.

55 Brisbane Courier, 16 January 1868: 3-4, 31 January 1868: 2, 7 February 1868: 3, 15 February 1868: 6, 21 February 1868: 2. See also Richards 2008: 18-19, 46, 95, 104.

56 Evans 2005: 59, 68. See also Richards 2008: 119-121, 185-200. 
perhaps 50 or 60 men - 'an uncommonly fine looking lot ... in very high spirits' carrying weapons, their hair whitened and their faces and chests painted yellow, white and brown to represent different clans. They lined up, the press noted, as neatly as soldiers, then marched in the royal parade, singing their 'war song', and stood to attention at the gates of Government House as the carriages passed through. ${ }^{57}$

These marchers had been invited by the organisers at the last minute, a decision which may have been hasty and taken without much thought. However, it occurred within an interesting context. The marchers gathered under the guidance of Thomas Petrie, a local colonist considered a 'friend to the Aborigines', who had known Indigenous people around Brisbane since his childhood, spoke a little of the Turrbal language, and had travelled with them in the Bunya range and employed them on his Pine Creek station. According to his daughter, Petrie knew that Indigenous people were being targeted, sometimes for atrocious violence, but felt powerless to intervene because the authorities implicitly supported it. ${ }^{58}$

Petrie's account only hinted, unfortunately, at how the Indigenous men experienced the Duke's welcome. Like many settlers in the crowd, they were disappointed by the Duke's plain dress; they had been expecting something like the grand attire worn by colonial officials. If the Indigenous men were performing their identity, they expected royalty to do the same. ${ }^{59}$ Nonetheless, they were happy, Petrie said, to receive half-a-crown each, plus oranges and biscuits; they gave three cheers for the queen and told him that they would be glad to appear like this again. ${ }^{60}$ This need not be seen as a straightforward performance for pay, however. These men may well have felt it appropriate to be the first people to welcome the Duke. Furthermore, any statement they intended about their own strength and dignity may not have been aimed at the Duke alone; great crowds of colonists were also watching. The Queensland newspaper coverage veered between arrogance, fascination and alarm. Few settlers knew about the plan to include the Aborigines, and their sudden arrival 'suggested to timid minds dreadful thoughts'.61 No doubt the organisers meant for the Indigenous presence to add an exotic touch, and perhaps having the Duke encounter them first of all was a re-enactment of an original moment of conquest. At the same time, though, the startled response of the crowd and the keen and dignified presence of the Indigenous men hinted at other possible understandings.

I have found no mention of any exchange between these marchers and the NMP. The presence of both groups of men conveyed mixed messages: implicitly denying the clashes taking place between this force and tribal people, but also serving as a visual reminder of the contrast between policing and 'savagery' - or

57 Petrie 1904: 210-212; Queensland Daily Guardian, 25 February 1868: 2; Queenslander, 29 February 1868: 2.

58 Hall 1974: 440-441; Petrie 1981[1904]: 1-9.

59 Petrie 1981[1904]: 210-212.

60 Petrie 1981[1904]: 210-212.

61 Queensland Daily Guardian, 25 February 1868: 2; Queenslander, 29 February 1868: 2. 
of the vulnerability of so-called savages against the police. This is reminiscent of recent discussions by scholars about the complex nature of the Australian 'frontier'. The frontier was traditionally imagined as a clear dividing line between colonised and uncolonised, 'civilised' and 'savage', which would naturally vanish as white settlement proceeded. However, scholars such as Lynette Russell, Richard Davis and Deborah Bird Rose have questioned this, demonstrating instead that frontiers could be lasting, layered and permeable; personal and cultural entities as well as geographical and temporal ones. ${ }^{62}$ At this celebration of monarchy, empire and settler progress, the theme of conquest was overt and uneasy - largely inarticulate, and yet startlingly present.

\section{New South Wales}

Indigenous performances also marked the Duke's visits to Sydney in February and March 1868. However, these pointed to different facets of colonialism. One notable event was a cricket match by a team of Jardwadjali, Gunditjmara and Wotjobaluk men from western Victoria. These athletes - managed and exploited by white sportsmen - had stolen out of Victoria against the protection board's orders and toured New South Wales. They appeared for the Duke just before leaving for their famous tour of England. Up to 9000 people watched them play at the Albert Cricket Ground against officers from the Duke's party, whom they outclassed. They then demonstrated athletics, spears, boomerangs and throwing sticks, and held a sham fight, dressed in black undergarments, possum skins and lyre-bird feathers. ${ }^{63}$ While their shows incorporated traditional skills and decorations, they were not welcoming their viewers or affirming links to their own country, as the performers in South Australia and perhaps Brisbane had done. Nor were they simply sportsmen. Rather, as David Sampson argues, they were part of a long tradition of 'professional savages' who travelled the world (willingly or unwillingly) performing versions of their 'native' selves for British audiences. At these matches, the men were shown as simultaneously savage and tame, and nakedness and violence were both signified and concealed. ${ }^{64}$ Such shows were easy to stage in New South Wales, where settler power was relatively secure but where there was no protection board to curtail Indigenous travel, commercialisation and display. Ann Curthoys has noted that this was an era of minimal state intervention in Indigenous affairs in New South Wales; the official stance was one of indifference and neglect. ${ }^{65}$

For the royal visit, a 'grand corroboree' was also planned at Clontarf, on the north side of Sydney Harbour, and this might have become a more profound occasion. According to the press, Indigenous people around Sydney had been keen to meet the Duke, and when it was announced that he would distributegiftsand blankets at a public celebration, about 300 people gathered. ${ }^{66}$

62 Davis 2005: 7; Rose 2005: 49; Rose and Davis 2005: iii; Russell 2001: 12-13.

63 Milner and Brierly 1869: 373-374; Sydney Morning Herald, 5 February 1868: 3, 6 February 1868: 2.

64 Sampson 1998: 54, 58-59, 62, 65; Sampson 2000: 1-30, 103-114, 172-173, 191-192.

65 Curthoys 1982: 31-35.

66 Sydney Morning Herald,29 February 1868: 5, 27 March 1868: 6. 
This was reminiscent of the old governor's feasts held in Parramatta in the early days, and for Indigenous people there may have been a lingering sense of the Crown recognising them (however inadequately) as the original owners of the land. ${ }^{67}$ The Sydney Empire said this was the largest Aboriginal gathering in the city that the current generation of colonists could recall. ${ }^{68}$ By the following decade, as Heather Goodall and Maria Nugent have noted, Sydney's Indigenous population would become larger, less welcome and more heavily controlled by the state, as the agricultural sector pushed more people out of their traditional districts. ${ }^{69}$ Their gathering for the Duke fell at the end of one era and the start of another.

They would be disappointed, however, and in a shocking way. The Duke was making his way to Cabbage Tree Beach, where the people were getting ready to dance, when a mentally disturbed Irishman called Henry James O'Farrell stepped out of the crowd and shot him. Alfred survived, but there was immediate chaos and an explosion of mob violence towards O'Farrell, the police and bystanders. The Indigenous crowd may have joined in this. With approval (and perhaps embroidering), the Sydney Empire noted:

The excitement and anger of the aborigines were as great, and more strongly expressed, than those of their white visitors; for upon learning that the assassin had not been summarily lynched on the spot, they asked for his body for the purpose of 'roasting him'.70

If Indigenous people had been invited to perform as exotic figures, they were incorporated here into another image of 'savagery', which was complex and ironic. It included the Aborigines (momentarily) in the body politic of enraged British subjects, while also displacing onto them the undoubtedly savage behaviour of the predominantly white crowd. A more subdued and humane response was voiced by an Indigenous man called John Weiman, who had travelled to Sydney with a group from Moruya to dance for the royal party. Weiman apparently wrote to friends that they had been looked after at the Duke's expense and were glad to hear that he was recuperating well. A certain royal connection and subjecthood were voiced here, but the chance for a greater public statement had been missed. ${ }^{71}$

67 Brook and Kohen 1991: 65-66, 72, 90-102; O'Brien 2008: 150-166; Reece 1974: 20, 125, 209-210.

68 Reproduced in the Argus, 1 April 1868: 5.

69 Goodall 1996: 104-105; Nugent 2005: 45-46.

70 Reproduced in the Argus, 1 April 1868: 5. The government searched unsuccessfully for a conspiracy, before hanging O'Farrell, amidst rising sectarian tensions. See Gibbney 1972: 128129; Sydney Morning Herald, 27 March 1868: 6.

71 Argus, 7 April 1868: 7. See also Argus, 5-6 February 1868: 5, 30 March 1868: 1 supplement; Brisbane Courier, 25 January 1868: 4, 4 March 1868: 2; Sydney Mail, 14 March 1868: 4. 


\section{Conclusion}

The meetings between the Duke of Edinburgh and Indigenous Australians highlight both the importance and the limitations of Indigenous links to the British Crown, in a setting where dispossession was severe and Indigenous people's material and political influence small. The people who welcomed the Duke obtained few tangible benefits, although it may have added to their political insight and public standing. These events can be added to a growing body of international scholarship which contemplates the curious bonds between the Crown and the native peoples of the lands seized in its name. ${ }^{72}$ At the same time, however, Alfred's receptions draw our attention to the peculiarly narrow options available to Indigenous Australians.

More broadly, these royal meetings can be seen as deeply paradoxical. They helped Indigenous people to reach out to the British Crown, but they occurred in an era when settlers' power was being consolidated - a factor which had prompted the royal tour in the first place. They allowed Indigenous people to challenge the usual order, but they could do so only through expressing loyalty to the imperial centre. This British loyalty, in turn, often required people to perform versions of native tradition, exoticism and difference, as well as compliance and 'civilisation'. This led to public displays which could both challenge and reinforce settler power and make visible the hierarchies and tensions of colonial life.

Studies such as this also draw our attention to the regional factors that shaped Australian histories. Historical accounts of Indigenous Australia and settlercolonialism have often focused on specific states or districts, while also taking Australian-ness and national boundaries rather for granted. New perspectives emerge from events like the Duke's tour, which functioned to both unite the colonies and highlight their differences, while also contributing to a more coherent discourse of settler-colonialism and racial thought. In turn, the imperial and transnational nature of the royal visit reminds us of how local dynamics of conquest, accommodation and resistance took place in a much wider setting, and affected it in turn. If there is something seductive about the freewheeling nature of many transnational histories and lives, the royal greetings staged by Indigenous people remind us of other understandings of space, and other costs incurred. These scenes were fleeting yet memorable. As one journalist remarked upon the Indigenous welcome for the Duke in Brisbane: 'For a moment the attention of the people was entirely diverted from the Prince to the strange guard which had been formed to do him honour ${ }^{\prime 73}$

72 Miller 2004; Radforth 2003.

73 Queensland Daily Guardian, 25 February 1868: 2; Queenslander, 29 February 1868: 2. 
ABORIGINAL HISTORY 2010 VOL 34

\section{References}

\section{Archival sources}

State Library of Victoria

Central Board Appointed to Watch over the Interests of the Aborigines 1863, Victoria: Third Report of the Central Board Appointed to Watch Over the Interests of the Aborigines in the Colony of Victoria, John Ferres, Melbourne.

- 1864, Victoria: Fourth Report of the Central Board Appointed to Watch Over the Interests of the Aborigines in the Colony of Victoria, John Ferres, Melbourne.

- 1869, Victoria: Sixth Report of the Central Board Appointed to Watch over the Interests of the Aborigines in the Colony of Victoria, John Ferres, Melbourne.

State Library of South Australia

Taplin, George, Diaries, 1867, PRG 186-1/12, vol 6, 4/5 fiche, Edith Gertrude Beaumont Papers, Adelaide.

\section{Newspapers}

Argus

Brisbane Courier

Geelong Advertiser

Geelong Register

Hamilton Spectator

Mercury

Perth Gazette and West Australian Times

Queensland Daily Guardian

Queenslander

Register

Sydney Mail

Sydney Morning Herald

Warrnambool Examiner 
INDIGENOUS AUSTRALIANS AND THE TOUR OF PRINCE ALFRED

\section{Secondary sources}

Anon 1867, Memoranda of Proceedings Connected with the Visit of His Royal Highness the Duke of Edinburgh, K.G. Ec., Ec, to South Australia, 1867, Andrews, Thomas, \& Clark, Adelaide.

- 1969, 'Baker, John (1813 - 1872)', Australian Dictionary of Biography, vol 3, Melbourne University Press, Melbourne: 75-76.

Barwick, Diane E 1998, Rebellion at Coranderrk, Aboriginal History Monograph series, Canberra.

Brook, J and JL Kohen 1991, The Parramatta Native Institution and the Black Town: a History, University of New South Wales Press, Kensington.

Broome, Richard 2005, Aboriginal Victorians: a History Since 1800, Allen \& Unwin, Crows Nest.

Bunce, Daniel 1856, Language of the Aborigines of the Colony of Victoria, and other Australian districts: with parallel translations and familiar specimens in dialogue as a guide to Aboriginal Protectors, and others engaged in ameliorating their condition, Slater, Williams and Hodgson, Melbourne.

Clark, Ian D 1990, Aboriginal Languages and Clans: an Historical Atlas of Western and Central Victoria, 1800-1900, Monash University, Melbourne.

- 2008, 'The northern Wathawurrung and Andrew Porteous, 1860-1877', Aboriginal History 32: 97-108.

Critchett, Jan 1992[1980], Our Land Till We Die: a History of the Framlingham Aborigines, Deakin University Press, Warrnambool.

Curthoys, Ann 1982, 'Good Christians and useful workers: Aborigines, Church and State in NSW, 1870-1883', in What Rough Beast? The State and Social Order in Australian History, Sydney Labour History Group (ed), Allen \& Unwin, Sydney: 31-56

- 1999, 'Expulsion, exodus and exile in white Australian historical mythology', Journal of Australian Studies 61: 1-18.

- 2002, 'Does Australian history have a future?' Australian Historical Studies 23(118): 140-152.

- 2008, 'Indigenous Subjects', in Australia's Empire, Deryck M Schreuder and Stuart Ward (eds), Oxford University Press, Oxford: 78-102.

Davis, Richard 2005, 'Introduction: transforming the frontier in contemporary Australia', in Dislocating the Frontier: Essaying the Mystique of the Outback, Deborah Bird Rose and Richard Davis (eds), ANU E Press, Canberra: 1-19. 
Deacon, Desley, Penny Russell and Angela Woollacott 2009, 'Introduction', in Transnational Ties: Australian Lives in the World, Desley Deacon, Penny Russell and Angela Woollacott (eds), ANU E Press, Canberra: xiii-xxi.

Evans, Julie 2005, 'Colonialism and the rule of law: the case of South Australia', in Crime and Empire, 1840-1940, Barry Godfrey and Graeme Dunstall (eds), William Publishing, Devon: 57-75.

Evans, Raymond 2007, A History of Queensland, Cambridge University Press, Cambridge.

Gibbney, HJ 1972, 'Edinburgh, Duke of (1844 - 1900)', Australian Dictionary of Biography, vol 4, Melbourne University Press, Melbourne: 128-129.

Goodall, Heather 1996, Invasion to Embassy: Land in Aboriginal Politics in New South Wales, 1700-1972, University of Sydney, Sydney.

Haebich, Anna and Jodie Taylor 2007, ‘Modern primitives leaping and stomping the earth: from ballet to bush doofs', Aboriginal History 31: 63-85.

Hall, Noeline 1974, 'Petrie, Thomas (1831-1910)', Australian Dictionary of Biography, vol.5, Melbourne University Press, Melbourne: 440-441

Holden, Roy H 1966, 'Bunce, Daniel (1813 - 1872)', Australian Dictionary of Biography, vol 1, Melbourne University Press, Melbourne: 176-177.

Jenkin, Graham 1979, Conquest of the Ngarrindjeri, Rigby, Adelaide.

Knight, JG 1868, Narrative of the Visit of His Royal Highness the Duke of Edinburgh to the Colony of Victoria, Australia, Mason, Firth \& Co, Melbourne.

Lambert, David and Alan Lester 2006, 'Imperial spaces, imperial subjects', in Colonial Lives Across the British Empire: Imperial Careering in the Long Nineteenth Century, David Lambert and Alan Lester (eds), Cambridge University Press, Cambridge: 1-31.

Lydon, Jane 2005, Eye Contact: Photographing Indigenous Australians, Duke University Press, Durham.

McCreery, Cindy 2004, 'The voyage of the Duke of Edinburgh in HMS Galatea to Australia, 1867-8', in Exploring the British World, Kate Darian-Smith, Patricia Grimshaw, Kiera Lindsey and Stuart Macintyre (eds), RMIT Publishing, Melbourne: 959-978.

- 2007,' "Long may he float on the ocean of life": the first royal visit to Tasmania, 1868', Tasmanian Historical Studies 12: 19-42. 
- 2008, 'A British prince and a transnational life: Alfred, Duke of Edinburgh's visit to Australia, 1867-8', in Transnational Ties: Australian Lives in the World, Desley Deacon, Penny Russell and Angela Woollacott (eds), ANU E-press, Canberra: 57-74.

McKenna, Mark 2004, This Country: A Reconciled Republic?, University of New South Wales Press, Sydney.

Miller, Jim 2004, 'Petitioning the Great White Mother: First Nations organizations and lobbying in London', in Reflections on Native-Newcomer Relations: Selected Essays, Jim Miller (ed), University of Toronto Press, Toronto: 217-241.

Milner, John and Oswald W Brierly 1869, The Cruise of H.M.S. Galatea, Captain H.R.H. The Duke Edinburgh, K.G., in 1867-1868, WH Allen \& Co, London.

Nugent, Maria 2005, Botany Bay: Where Histories Meet, Allen \& Unwin, Crows Nest.

O'Brien, Anne 2008, " "Kitchen fragments and garden stuff": poor law discourse and Indigenous people in early colonial New South Wales', Australian Historical Studies 39(2): 150-166.

Parsons, Michael 1997, 'The tourist corroboree in South Australia to 1911', Aboriginal History 21: 46-69.

- 2002, "“Ah that I could convey a proper idea of this interesting wild play of the natives": corroborees and the rise of Indigenous Australian cultural tourism', Australian Aboriginal Studies 1: 14-26.

Petrie, Constance Campbell, 1981[1904], Tom Petrie's Reminiscences of Early Queensland, Watson, Ferguson \& Co, Brisbane.

Radforth, Ian 2003, 'Performance, politics and representation: Aboriginal people and the 1860 royal tour of Canada', Canadian Historical Review 84(1): 1-33.

Reece, RHW 1974, Aborigines and Colonists: Aborigines and Colonial Society in New South Wales in the 1830s and 1840s, Sydney University Press, Sydney.

Reynolds, Henry 2001, An Indelible Stain? The Question of Genocide in Australia's History, Viking, Ringwood.

- 2004[1995], Fate of a Free People, Penguin, Camberwell.

Richards, Jonathon, 2008, The Secret War: a True History of Queensland's Native Police, University of Queensland Press, St Lucia.

Rose, Deborah Bird 2005, 'The redemptive frontier: a long road to nowhere', in Dislocating the Frontier: Essaying the Mystique of the Outback, Rose and Davis (eds), ANU E Press, Canberra: 49-65. 
- and Richard Davis 2005, 'Preface', in Dislocating the Frontier: Essaying the Mystique of the Outback, Rose and Davis (eds), ANU E Press, Canberra: iii-iv.

Russell, Lynette 2001, 'Introduction', in Colonial Frontiers: Indigenous-European Encounters in Settler Societies, Lynette Russell (ed), Manchester University Press, Manchester: 1-16.

Rutledge, Martha 1967, 'Rutledge, William (1806 - 1876)', Australian Dictionary of Biography, vol 2, Melbourne University Press, Melbourne: 411-412.

Sampson, David 1998, "The nature and effects thereof were ... by each of them understood": Aborigines, agency, law and power in the 1867 Gurnett contract', Labour History 74, May: 54-69.

- 2000, Strangers in a Strange Land: The 1868 Aborigines and Other Indigenous Performers in Mid-Victorian Britain, University of Technology (Australasian Digital Theses Program), Sydney.

Schreuder, Deryck M and Stuart Ward 2008, 'Introduction: what became of Australia's empire?', in Australia's Empire, Schreuder and Ward (eds): 1-24.

Taplin, George 1879[1873], 'The Narrinyeri', in The Native Tribes of South Australia, JD Woods (ed), ES Wigg \& Son, Adelaide: 1-156.

Tyrell, Alex, with Yvonne Ward 2000, "'God Bless Her Little Majesty": the popularising of monarchy in the 1840s', National Identities 2(2): 109-125.

Tyrell, Ian 2001, 'New comparisons, international worlds: transnational and comparative perspective', Australian Feminist Studies 16(36): 355-361.

Woods, JD 1868, A Narrative of the Visit of H.R.H. the Duke of Edinburgh, K.G., to South Australia, Chas. Platts \& Co, Adelaide. 